\title{
EXPERIMENTAL AND ANALYTICAL STUDY ON CONCRETE WITH PARTIAL REPLACEMENT OF COARSE AGGREGATE BY PLASTIC WASTE
}

\author{
J.Amirtharaj \\ B.E., M.Tech., Research Associate \\ Aristocrat It solutions
}

\begin{abstract}
The utilization of waste in a concrete is major attempt in current situation, because of the pollution; there is a great harm to nature and human life. Plastic is chosen to minimize stack piling of waste in environment and to control pollution. Nowadays, in the construction industries, the availability of coarse aggregate is major problem. Thus minimizing the availability of gravel in the making of concrete, many alternatives investigations are carried out. In this research work, the coarse aggregate is partially replaced by $10 \%$ and $20 \%$ of plastic waste. The cube specimens of size $150 \mathrm{~mm} \times 150 \mathrm{~mm} \times 150 \mathrm{~mm}$ were casted with the various percentage replacements of plastic wastes to determine the compressive strength and developing the linear equation to determine the predicted values using the experimental data set. The concrete mix with $10 \%$ partial replacement of coarse aggregate with plastic waste shows higher strength.
\end{abstract}

Keywords: compressive strength plastic waste, simple linear regression

\section{INTRODUCTION}

Concrete is a major construction materials, which are being used in the construction industry. The various components of concrete includes cement, fine aggregate, coarse aggregate, water and any admixtures. From these, maximum quantity of component used in the concrete is coarse aggregate. Use of the naturally available material like coarse aggregate leads to deplete the natural resources, unless there is a suitable alternative material. Plastic waste material is often used as a partial replacement of coarse aggregate reducing the cost of the construction. Hence, these plastic materials are very harmful, if we dispose in land, such as it affects the fertility of the soil. If we burn these plastic materials, it releases the $\mathrm{CO}_{2}$, which affects the environments.

\subsection{Generation of plastics}

India generates 25,940 tonne of plastic waste every day. As per estimates by central pollution control board (CPCB), plastic waste generated per year is 660787.85 tonne. The word plastic means substances which have plasticity and accordingly anything formed in a soft state and used in solid state can be called as a plastic. Plastics can be separated into two types namely thermoplastic and thermosetting plastics. The thermoplastic are melted in plastic industry. These plastics are polyethylene, polypropylene, polyamide. The thermosetting plastics is plastic which cannot be melted because of molecular chains are bonded with meshed crosslink. These plastics are phenolic, unsaturated polyester, epoxy resin, silicone. At present these are disposed by burning or burying. Instead of burning or burying, the attempts have been made in used in construction industry

\section{LITERATURE REVIEW}

The introduction of plastic waste as coarse aggregate can helps in reduction of cost and increases the strength up to some extent. The introduction of plastic waste in concrete make ductile, hence develop the ability of ductility before failure [11].The addition of plastic waste into the concrete by partial replacement of coarse aggregate by $10 \%$ shows increases in compressive, tensile and flexural strength [2]. The drop in strength is due to low bond strength between cement paste and aggregate and also due low strength of plastics[10].The workability of concrete mix increases with increasing the percentage replacement of plastic waste [11].The 10\% 
replacement of E-Plastic waste shows good in compressive strength [1]. The addition of plastics in concrete mix helps in reduction of total weight of concrete [11].The reduction of total weight is more advantages, which helps in reduction of materials like reinforcements; etc.

\section{MATERIAL USED}

Cement: The OPC 53 grade is used in the research work conforming to IS: $12269: 1987$. the specific gravity of cement is 3.15 and standard consistency of $29 \%$ and initial setting time of 30 minutes and final setting timer of 600 minutes.

Fine aggregate: Natural sand of size which passing the $4.75 \mathrm{~mm}$ sieve is taken for research work. The specific gravity of fine aggregate is 2.65 . The fine aggregate is corresponds to zone-II. The unit weight of fine aggregate is $1622 \mathrm{~kg} / \mathrm{m}^{3}$. The fineness modulus of fine aggregate is 2.9 .

Coarse Aggregate: The coarse aggregate is a crushed angular which was passing in $20 \mathrm{~mm}$ sieve is used in the research work. The specific gravity of fine aggregate is 2.7 . The unit weight of fine aggregate is $1800 \mathrm{~kg} / \mathrm{m}^{3}$. The fineness modulus of coarse aggregate is 6.5 .

Water: The portable water which is free from deleterious materials with ph of 7 .

Super plasticizer: The super plasticizer is used to impart workability to concrete, because the addition of fiber affects the workability of concrete. The poly carboxylic ether form of super plasticizer named CONXL PCE DM-09 is used at $0.6 \%$ by weight of cement.

Plastic Waste: The crushed plastic waste which passing on $20 \mathrm{~mm}$ sieve and retained on $4.75 \mathrm{~mm}$ sieve are taken and used in this research work. The fineness modulus of plastic waste is 6.9.

\section{METHODOLOGY}

\subsection{Mix Design}

The mix design can be done as per IS10262:2009 for M20 Grade Concrete.The mix proportion was found to be 1:1.86:2.89 with watercement ratio as 0.40 .
Table: 1 Mix proportion for various concrete mixes

\begin{tabular}{|c|c|c|c|c|c|c|}
\hline $\begin{array}{c}\text { \% of } \\
\text { Plastic } \\
\text { Waste }\end{array}$ & $\begin{array}{c}\text { Cement } \\
\left(\mathbf{K g} / \mathbf{m}^{3}\right)\end{array}$ & $\begin{array}{c}\text { Fine } \\
\text { Aggregate } \\
\left(\mathbf{K g} / \mathbf{m}^{\mathbf{3}}\right)\end{array}$ & $\begin{array}{c}\text { Coarse } \\
\mathbf{A g g r e g a t e} \\
\left(\mathbf{K g} / \mathbf{m}^{\mathbf{3}}\right)\end{array}$ & $\begin{array}{c}\text { Plastic } \\
\text { waste } \\
\left(\mathbf{K g} / \mathbf{m}^{3}\right)\end{array}$ & $\begin{array}{c}\text { Water } \\
\left(\mathbf{g m} / \mathbf{m}^{3}\right)\end{array}$ & $\begin{array}{c}\text { Super } \\
\text { Plasticizer } \\
\left(\mathbf{g m} / \mathbf{m}^{\mathbf{3}}\right)\end{array}$ \\
\hline 0 & 400 & 746 & 1156 & - & 160 & 2.4 \\
\hline 10 & 400 & 746 & 1040.4 & 115.6 & 160 & 2.4 \\
\hline 20 & 400 & 746 & 924.8 & 231.2 & 160 & 2.4 \\
\hline
\end{tabular}

\subsection{Casting of specimen}

The concrete mix is mixed with the partial replacement of coarse aggregate with $0 \%, 10 \%$ and $20 \%$ of plastic waste. Then cement and fine aggregate is mixed initially, followed by addition of coarse aggregate and plastic waste. After this, super plasticizer is added in the required quantity of water. Now, the super plasticizer mixed in the water is added into the concrete. The concrete mix is filled in mould in 3 layers. Each layer is tamped by 25 blows.

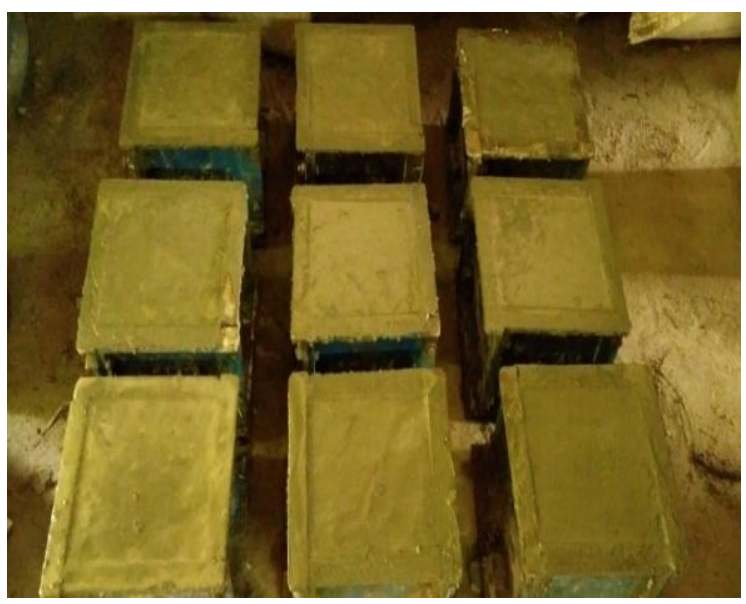

Fig: 1 Cube Test Specimen

4.3 Testing of specimens: The test can be performed as per IS: 516-1959. The compressive strength of concrete was in determined by using universal testing machine. The three specimen of cube with the size of 150x150x150mm were tested for 7, 14 and 28 days of curing. Average compressive strength of concrete at each age was determined by taking the average of three specimens. The compressive strength can be computed by using the formulae; 


\section{Compressive strength $=P / A$}

$\mathrm{P}=\mathrm{Load}$ at failure of specimen in $\mathrm{N}$.

$\mathrm{A}=$ Surface area of specimen in $\mathrm{mm}^{2}$

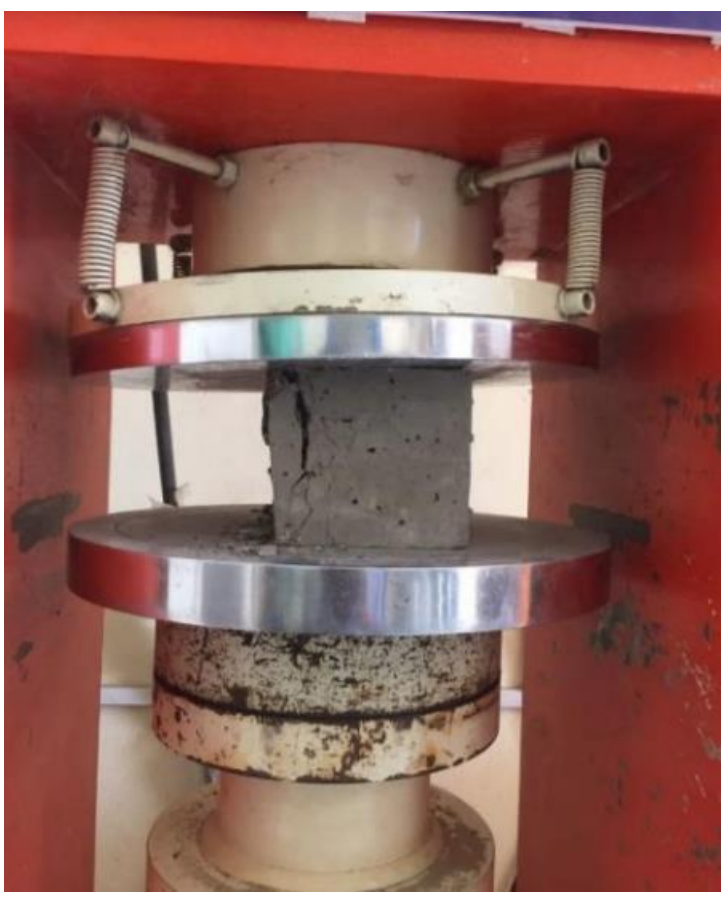

Figure: 1 Compressive Strength Testing

\section{RESULTS}

The results are obtained by testing the test specimen in the universal testing. Three samples are tested for $0 \%, 10 \%$ and $20 \%$ replacement of plastic waste at 7, 14 and 28 days of curing. The average values of three samples are taken and presented below,

Table: 2 Compressive Strength for 0\% Replacement of Plastic Waste at 7 Days

\begin{tabular}{|c|c|c|c|}
\hline $\begin{array}{l}\text { Specimen } \\
\text { Id }\end{array}$ & $\begin{array}{l}\text { Load } \\
\text { at } \\
\text { Failure } \\
(\mathbf{k N})\end{array}$ & $\begin{array}{l}\text { Compressive } \\
\text { Strength } \\
\left(\mathrm{N} / \mathbf{m m}^{2}\right)\end{array}$ & $\begin{array}{l}\text { Average } \\
\text { Compressive } \\
\text { Strength } \\
\left(\mathbf{N} / \mathbf{m m}^{2}\right)\end{array}$ \\
\hline $\begin{array}{l}0 \%-7 \mathrm{D}- \\
\mathrm{S} 1\end{array}$ & 512 & 22.72 & \multirow{3}{*}{22.5} \\
\hline $\begin{array}{l}0 \%-7 \mathrm{D}- \\
\text { S2 }\end{array}$ & 500 & 22.2 & \\
\hline $\begin{array}{l}0 \%-7 \mathrm{D}- \\
\mathrm{S} 3\end{array}$ & 510 & 22.6 & \\
\hline
\end{tabular}

Table: 3 Compressive Strength for 0\% Replacement of Plastic Waste at 14 Days

\begin{tabular}{|c|c|c|c|}
\hline $\begin{array}{l}\text { Specimen } \\
\text { Id }\end{array}$ & $\begin{array}{l}\text { Load at } \\
\text { Failure } \\
(k N)\end{array}$ & $\begin{array}{l}\text { Compressiv } \\
\text { e Strength } \\
\left(\mathrm{N} / \mathrm{mm}^{2}\right)\end{array}$ & 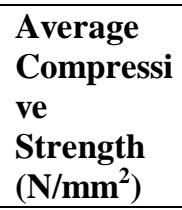 \\
\hline $\begin{array}{l}0 \%-14 \mathrm{D}- \\
\mathrm{S} 1\end{array}$ & 560 & 24.88 & \multirow{3}{*}{24.9} \\
\hline $\begin{array}{l}0 \%-14 \mathrm{D}- \\
\mathrm{S} 2\end{array}$ & 555 & 24.66 & \\
\hline $\begin{array}{l}0 \%-14 \mathrm{D}- \\
\mathrm{S} 3\end{array}$ & 568 & 25.24 & \\
\hline
\end{tabular}

Table: 4 Compressive Strength for 0\% Replacement of Plastic Waste at 28 Days

\begin{tabular}{|l|l|l|l|}
\hline $\begin{array}{l}\text { Specimen } \\
\text { Id }\end{array}$ & $\begin{array}{l}\text { Load } \\
\text { at } \\
\text { Failure } \\
(\mathbf{k N})\end{array}$ & $\begin{array}{l}\text { Compressive } \\
\text { Strength } \\
\left(\mathbf{N} / \mathbf{m m}^{2}\right)\end{array}$ & $\begin{array}{l}\text { Average } \\
\text { Compressive } \\
\text { Strength } \\
\left(\mathbf{N} / \mathbf{m m}^{2}\right)\end{array}$ \\
\hline $\begin{array}{l}\text { 0\%-28D - } \\
\text { S1 }\end{array}$ & 668 & 29.68 & \\
\cline { 1 - 2 } $\begin{array}{l}0 \%-28 \mathrm{D} \\
-\mathrm{S} 2\end{array}$ & 668 & 29.68 & \multirow{2}{*}{$\mathbf{2 9 . 6}$} \\
\cline { 1 - 2 } $\begin{array}{l}\text { 0\%-28D } \\
-\mathrm{S} 3\end{array}$ & 665 & 29.5 & \\
\hline
\end{tabular}

Table: 5 Compressive Strength for $10 \%$ Replacement of Plastic Waste at 7 Days

\begin{tabular}{|l|l|l|l|}
\hline $\begin{array}{l}\text { Specimen } \\
\text { Id }\end{array}$ & $\begin{array}{l}\text { Load at } \\
\text { Failure } \\
(\mathbf{k N})\end{array}$ & $\begin{array}{l}\text { Compressive } \\
\text { Strength } \\
\left(\mathbf{N} / \mathbf{m m}^{2}\right)\end{array}$ & $\begin{array}{l}\text { Average } \\
\text { Compressive } \\
\text { Strength } \\
\left(\mathbf{N} / \mathbf{m m}^{2}\right)\end{array}$ \\
\hline $\begin{array}{l}\text { 10\%-7D - } \\
\text { S1 }\end{array}$ & 568 & 25.24 & \\
\cline { 1 - 2 } $\begin{array}{l}10 \%-7 \mathrm{D}- \\
\text { S2 }\end{array}$ & 569 & 25.29 & \multirow{2}{*}{$\mathbf{2 5 . 5}$} \\
\cline { 1 - 2 } $\begin{array}{l}10 \%-7 \mathrm{D}- \\
\text { S3 }\end{array}$ & 584 & 25.96 & \\
\hline
\end{tabular}


Table: 6 Compressive Strength for $10 \%$ Replacement of Plastic Waste at 14 Days

\begin{tabular}{|l|l|l|l|}
\hline $\begin{array}{l}\text { Specimen } \\
\text { Id }\end{array}$ & $\begin{array}{l}\text { Load } \\
\text { at } \\
\text { Failure } \\
(\mathbf{k N})\end{array}$ & $\begin{array}{l}\text { Compressive } \\
\text { Strength } \\
\left(\mathbf{N} / \mathbf{m m}^{2}\right)\end{array}$ & $\begin{array}{l}\text { Average } \\
\text { Compressive } \\
\text { Strength } \\
\left(\mathbf{N} / \mathbf{m m}^{2}\right)\end{array}$ \\
\hline $\begin{array}{l}10 \%-14 \mathrm{D} \\
-\mathrm{S} 1\end{array}$ & 624 & 27.73 & \\
\cline { 1 - 2 } $\begin{array}{l}10 \%-14 \mathrm{D} \\
-\mathrm{S} 2\end{array}$ & 601 & 26.71 & \multirow{2}{*}{$\mathbf{2 7 . 4 2}$} \\
\cline { 1 - 2 } $\begin{array}{l}10 \%-14 \mathrm{D} \\
-\mathrm{S} 3\end{array}$ & 626 & 27.82 & \\
\hline
\end{tabular}

Table: 7 Compressive Strength for $10 \%$ Replacement of Plastic Waste at 28 Days

\begin{tabular}{|c|c|c|c|}
\hline $\begin{array}{l}\text { Specimen } \\
\text { Id }\end{array}$ & $\begin{array}{l}\text { Load } \\
\text { at } \\
\text { Failure } \\
(\mathbf{k N})\end{array}$ & $\begin{array}{l}\text { Compressive } \\
\text { Strength } \\
\left(\mathrm{N} / \mathbf{m m}^{2}\right)\end{array}$ & $\begin{array}{l}\text { Average } \\
\text { Compressive } \\
\text { Strength } \\
\left(\mathbf{N} / \mathbf{m m}^{2}\right)\end{array}$ \\
\hline $\begin{array}{l}10 \%-14 \mathrm{D} \\
-\mathrm{S} 1\end{array}$ & 698 & 31.02 & \multirow{3}{*}{31.24} \\
\hline $\begin{array}{l}10 \%-14 \mathrm{D} \\
-\mathrm{S} 2\end{array}$ & 688 & 30.58 & \\
\hline $\begin{array}{l}10 \%-14 \mathrm{D} \\
-\mathrm{S} 3\end{array}$ & 723 & 32.13 & \\
\hline
\end{tabular}

Table: 8 Compressive Strength for $20 \%$ Replacement of Plastic Waste at 7 days

\begin{tabular}{|c|c|c|c|}
\hline $\begin{array}{l}\text { Specimen } \\
\text { Id }\end{array}$ & $\begin{array}{l}\text { Load } \\
\text { at } \\
\text { Failur } \\
\text { e (kN) }\end{array}$ & $\begin{array}{l}\text { Compress } \\
\text { ive } \\
\text { Strength } \\
\left(\mathbf{N} / \mathbf{m m}^{2}\right)\end{array}$ & $\begin{array}{l}\text { Average } \\
\text { Compressiv } \\
\text { e Strength } \\
\left(\mathrm{N} / \mathbf{m m}^{2}\right)\end{array}$ \\
\hline $\begin{array}{l}20 \%-7 D- \\
S 1\end{array}$ & 352 & 15.64 & \multirow{3}{*}{16.09} \\
\hline $\begin{array}{l}20 \%-7 D- \\
S 2\end{array}$ & 372 & 16.53 & \\
\hline $\begin{array}{l}20 \%-7 D- \\
\text { S3 }\end{array}$ & 362 & 16.09 & \\
\hline
\end{tabular}

Table: 9 Compressive Strength for $20 \%$ Replacement of Plastic Waste at 14 days

\begin{tabular}{|l|l|l|l|}
\hline $\begin{array}{l}\text { Specimen } \\
\text { Id }\end{array}$ & $\begin{array}{l}\text { Load } \\
\text { at } \\
\text { Failure } \\
(\mathbf{k N})\end{array}$ & $\begin{array}{l}\text { Compressive } \\
\text { Strength } \\
\left(\mathbf{N} / \mathbf{m m}^{2}\right)\end{array}$ & $\begin{array}{l}\text { Average } \\
\text { Compressive } \\
\text { Strength } \\
\left(\mathbf{N} / \mathbf{m m}^{2}\right)\end{array}$ \\
\hline $\begin{array}{l}20 \%-14 \mathrm{D} \\
-\mathrm{S} 1\end{array}$ & 524 & 23.29 & \\
\cline { 1 - 2 } $\begin{array}{l}\text { 20\%-14D } \\
-\mathrm{S} 2\end{array}$ & 498 & 21.73 & \multirow{2}{*}{$\mathbf{2 3 . 2 7}$} \\
\cline { 1 - 2 } $\begin{array}{l}\text { 20\%-14D } \\
-\mathrm{S} 3\end{array}$ & 558 & 24.80 & \\
\hline
\end{tabular}

Table: 10 Compressive Strength for $20 \%$ Replacement of Plastic Waste at 28 days

\begin{tabular}{|c|c|c|c|}
\hline $\begin{array}{l}\text { Specimen } \\
\text { Id }\end{array}$ & $\begin{array}{l}\text { Load } \\
\text { at } \\
\text { Failure } \\
(\mathbf{k N})\end{array}$ & $\begin{array}{l}\text { Compressive } \\
\text { Strength } \\
\left(\mathrm{N} / \mathbf{m m}^{2}\right)\end{array}$ & $\begin{array}{l}\text { Average } \\
\text { Compressive } \\
\text { Strength } \\
\left(\mathbf{N} / \mathbf{m m}^{2}\right)\end{array}$ \\
\hline $\begin{array}{l}20 \%-28 \mathrm{D} \\
-\mathrm{S} 1\end{array}$ & 650 & 28.88 & \multirow{3}{*}{28.8} \\
\hline $\begin{array}{l}20 \%-28 \mathrm{D} \\
-\mathrm{S} 2\end{array}$ & 645 & 28.66 & \\
\hline $\begin{array}{l}20 \%-28 \mathrm{D} \\
-\mathrm{S} 3\end{array}$ & 650 & 28.88 & \\
\hline
\end{tabular}

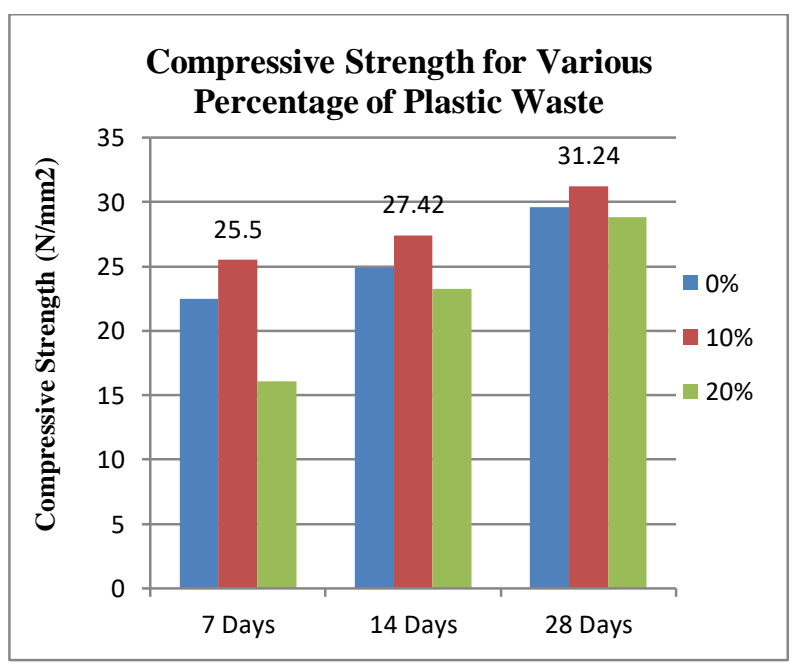

Fig: 2 Compressive Strength Vs \% Replacement of Plastic Waste

\section{Statistical Evaluation of results}

The simple linear regression was utilized to obtain the compressive strength results for the 
various partial replacement of coarse aggregate with the plastic wastes. The simple linear regression can be carried by considering the percentage replacement of coarse aggregate as independent variable and the compressive results as dependent variables. The equation obtained from the linear regression is,

$$
y=-4 x+30.28 \quad \text {-equation (1) }
$$

where $\mathrm{y}$ is the dependent variable and $\mathrm{x}$ is the independent variable.

With reference to the experimental results, the equation (1) can be used to determine the compressive strength for the various percentage replacement of coarse aggregate by the plastic waste concrete. The errors in predicted values is caused by the numerous reasons like physical and chemical composition of cement, aggregate, water, methods of mixing, placing and properties of plastics used.

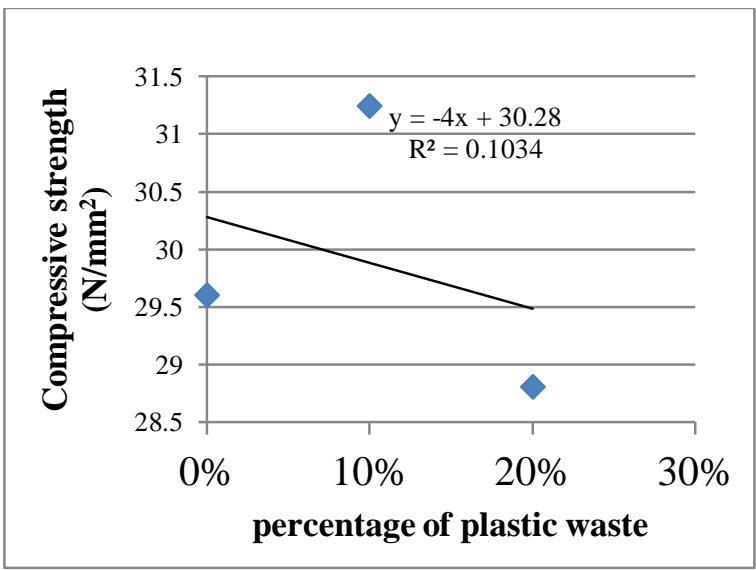

Fig: 3 Linear regression sketch

\section{CONCLUSIONS}

- The addition of crushed plastic waste shows increases the compressive strength up to $10 \%$, after $10 \%$ replacement of coarse aggregate with plastic waste show decrease in the compressive strength. These decreases of compressive strength is due to quantity of cement paste between the plastic waste is low, because the plastic waste occupies more spaces in the concrete mix, as percentage replacement increases.

- The Compressive strength increases from $0 \%$ to $10 \%$ replacement of coarse aggregate with plastic waste.

- The compressive strength decreases from $10 \%$ to $20 \%$ replacement of coarse aggregate with plastic waste.
- The optimum percentage replacement of coarse aggregate with plastic waste is to be $10 \%$.

- The maximum percentage increase in compressive strength is $40 \%$.

- The maximum percentage decrease in compressive strength is $8 \%$.

- The simpler linear regression equation shows that there is good relation between the experimental and the predicted values.

\section{LIMITATIONS}

In these proposed investigation, the simple linear equation gives the correlation of good. However, increasing the number of the variables the accuracy of prediction will increases.

\section{REFERENCES}

1. Ashwini Manjunathan.B.T. (2015). Partial Replacement of E-Plastic Waste as a Coarse Aggregate in Concrete, International Conference on Solid Waste Management, (pp.731-739).

2. Dhaarani.D, Shanumuganathan.N, Gokila.M, Akshaya.A, Abirami.D, Dhilshanth Begam.J. (2017). Crushed Plastic Waste in Concrete, International Research Journal Engineering and Technology, Vol.5, No.3, (pp. 3638-3640).

3. IS: 10262-2009, Concrete Mix Proportioning

4. IS: 383-1970, Specification for Fine and Coarse Aggregate

5. IS: 516-1959, Methods of Tests for Strength of Concrete

6. J.Shah, J.Chandra, I.Rastandi, E.Arijoeni. (2018). The Effect of usage of Crushed Polypropylene Plastic Waste in Mechanical Properties of Concrete, International Journal of Civil Engineering and Technology, Vol.9, No.7, (pp.1495-1505).

7. Khademi .F and Behfarnia.K. (2016). Evaluation of Compressive Strength using Artificial Neutral Network and Multiple Linear Regression Models, International Journals of optimization in Civil Engineering, Vol.6, No.3, (pp.423-432).

8. Lhakpa Wangmo and Thingh Tamang. (2017).Use of Plastics in Concrete as Coarse Aggregate, International Journal of Education and Applied Sciences, Vol.7, No.2, (pp.9-13).

9. Mastan Vali.N and S.Asadi. (2018). Pet Bottle Waste as a Supplement Concrete Fine Aggregate, International Journal of Civil Engineering and Technology, Vol.8, No.1, (pp.558-568). 
10. P.Sravanya. (2017). Variations in Strength of Concrete by using Waste Plastic as Coarse Aggregate Replacement Material, International Journal of Innovative Technologies, (pp. 603607).

11. Rafiq Ahmed Pirzada. (2018). Experimental Study on use of Waste Plastic as Coarse Aggregate with Admixture Super plasticizer Poly Carboxylate Ether, International Research Journal of Engineering and Technology, (pp.558-563)

12. S.Vanitha, V.Natarajan and M.Prabhu. (2015). Utilization of Waste Plastic as a Partial Replacement of Coarse Aggregate in Concrete Block, Indian Journal of Science and Technology, Vol.8, No. 12, (pp:1-6).

13. Shalini.J,Ravikumar.M.S, Nalanthan.N and Kannan.S.U. (2018). Effective Utilization of Plastic Waste Material in the Production of Environmental Friendly Concrete, International Journal Of Civil Engineering and Technology, Vol. 9, No. 13, (pp.1478-1486).

14. Singh Vijay Pa. (2013). Prediction of Concrete Strength using Artificial Neutral Network, Engineering Structures, Vol. 25, (pp.849-857).

15. Subramani.T and Pugal.V.K. (2017). "Experimental Study on Plastic Waste as a Coarse Aggregate for Structural Concrete" International Journal of Application or Innovation in Engineering and Management, Vol.4, No.5, (pp.144-152). 